\title{
1. Introduction: can Russia and its oil companies handle change?
}

This book examines Russia's capacity to respond to a changing world, as seen through the lens of the country's oil companies. The reasons for this choice of topic are the central role of the petroleum sector in the Russian economy, the great importance of Russian oil and gas to the world's energy supply and the rapid pace of change in the global energy industry. The petroleum sector accounts for $40 \%$ of the Russian state's income (TASS 2018) and employs over 1.1 million people, with more than 400000 working for Gazprom alone. Russia is also the world's largest energy exporter, and Russian foreign policy is interwoven with market access, cooperation and investments in the energy sector (Casier 2011; Hendrix 2015; Jirušek et al. 2017; Kalehsar and Telli 2017; Proedrou 2017; Wigell and Vihma 2016).

The Kremlin maintains a firm grip on Russia's oil and gas industry by controlling the largest producers, Gazprom and Rosneft, by setting framework conditions for the operations of other companies and by doling out tax breaks and other privileges to preferred actors. However, the actual work in the petroleum sector is done by the companies themselves, regardless of whether they are wholly or partially privately owned. How these companies cope with a changing world is decisive for the fate of the Russian petroleum industry and thus for Russia. This book, therefore, focuses on these organizations rather than the role of the state.

\section{THE CHALLENGE OF CHANGE}

Russian oil companies must deal with many types of change, such as oil price swings, currency fluctuations, the rise of shale oil, Western sanctions over the conflict in Ukraine, the shift of oil consumption growth to Asia and the increasing salience of climate policy. In the long term, the most important of these may be climate policy, which is upending the global energy system.

World energy markets are subject to continuous incremental change and occasional technology-driven tsunamis referred to as 'energy transitions' (Fouquet 2016; Fouquet and Pearson 2012; Grubler 2012; Meadowcroft 2009; Smil 2010). Past energy transitions have been associated with the emergence 
of disruptive technologies, such as electricity, the internal combustion engine and nuclear power. Climate policy is now driving a new energy transition towards renewable energy, especially solar and wind power. This transition may change international demand for the products of Russian oil companies, in addition to putting pressure on the companies to reduce their direct emissions. How Russia and its oil companies deal with this and other changes will be one determinant of the country's strength in global affairs (Overland and Kjaernet 2009).

Many East Asian and Western companies are locked in battles of innovation and counter-innovation - for example Apple, Huawei and Samsung in telephony; or Build Your Dreams (BYD), Nissan and Tesla in road transport. To play a role in the evolving world, Russia's major companies must be able to manage change and, ideally, even become its drivers. If there is one area where they have a chance of doing this, it is in the petroleum sector, where they have such a strong position and rich history. It dates all the way back to the first oil well and refinery in the town of Ukhta in the Komi Republic in 1745. Russia's current position as the world's biggest combined oil and gas exporter could also, in principle, give it an upper hand in driving change (Poussenkova and Overland 2018, p. 261).

\section{HYPOTHESIS: RUSSIAN OIL COMPANIES LACK FORESIGHT}

This book seeks to answer two main questions. First: How are Russian oil companies tackling the changing global context? This question concerns both how Russian actors think about the future and plan for it, and how they handle change once it happens. In other words, this question is about the adaptability of Russian actors. Second: How are the companies themselves changing? This concerns the people in charge, their corporate culture and political connections and the companies' oil reserves.

Our working hypothesis is that Russian organizations, including oil companies, are not good at foreseeing and adapting to change. Gustafson (2012, p. 2) writes that 'despite two decades of tumultuous changes, the pull of the past - of the assets and mindsets of the Soviet legacy - remains strong. Yet the Russian oil industry is now exposed to a global energy system that is itself experiencing a revolution. Consequently, it too is under pressure to change.' Dixon (2008, p. 42) adds that 'in transition economies, many of the big state-owned enterprises have become corporate dinosaurs, entrenched in old behaviours and unable to make the first steps of change to adapt to a changing environment' (also see Peng 2000). 
We present our hypothesis in the spirit of Popper - as something to try to shoot down. However, it is not difficult to find anecdotal evidence from Russian history to back it up. The Communist Party appeared unprepared for the steep decline of the oil price in the 1980s, and both the party and Soviet society at large seemed to be caught unawares by the unravelling of the Soviet Union in 1991, to which the low oil price greatly contributed (Friedman 2006; Kotkin 2008; Reynolds and Kolodziej 2008). Since then, Russian oil companies have matured, worked closely with their international counterparts and expanded into foreign upstream and downstream markets (Henderson and Ferguson 2014). Nonetheless, for years, they continued to deny the significance of the shale revolution (Davydova 2017b; Grealy 2012; Spencer and Hansen 2012). Russian energy actors (along with some of their Western colleagues) have also been among the world's most entrenched climate sceptics, even though Russia is a signatory to both the Kyoto Protocol and the Paris Agreement.

One possible explanation for this laggardness could be the age and gender composition of the top managers of the Russian oil companies. They tend to be exclusively elderly men, few of whom have any foreign education (Figures 1.1-1.3).

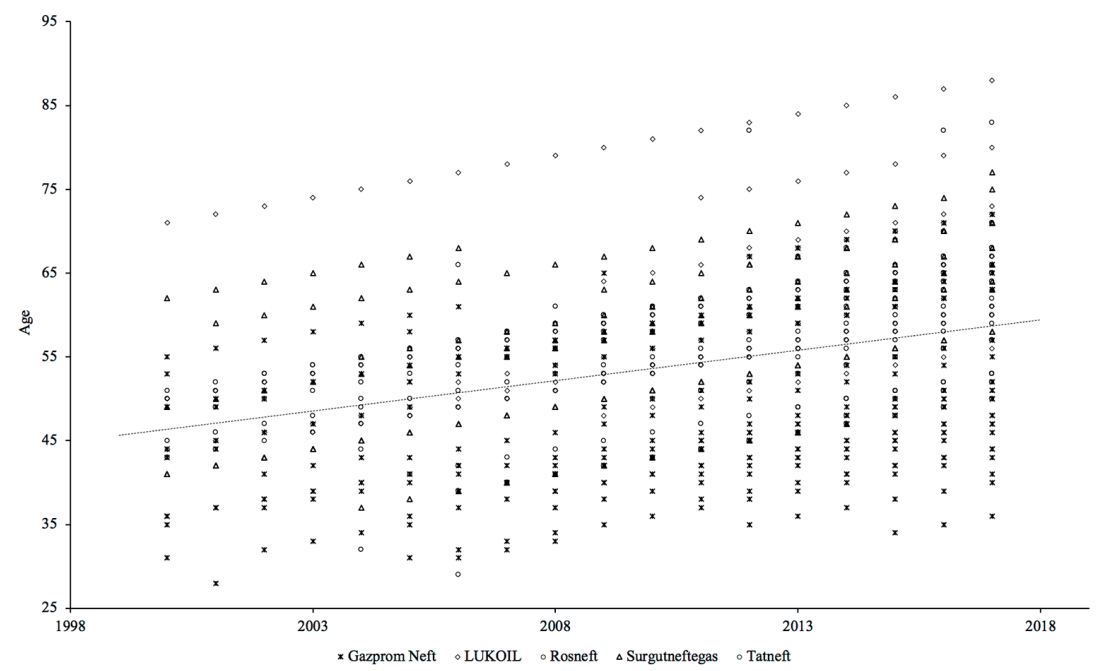

Figure 1.1 Age of CEOs and board members of Russian oil companies

Source: Compiled by the authors based on a large number of sources. 


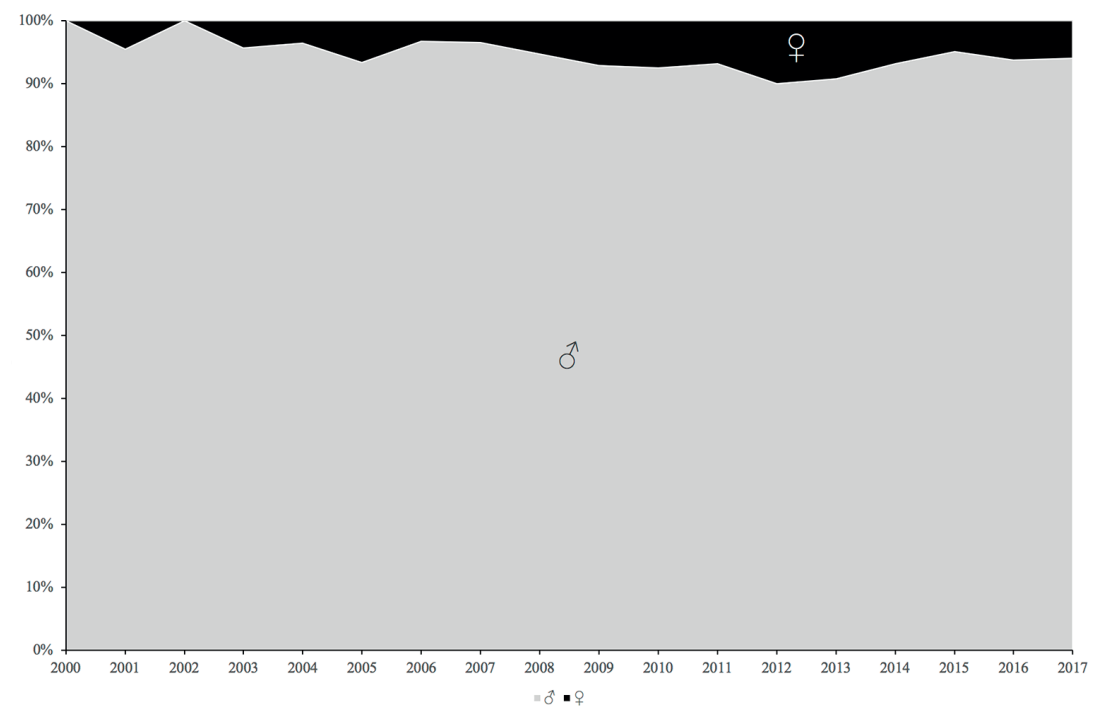

Figure 1.2 Gender of CEOs and board members of Russian oil companies

Source: Compiled by the authors based on a large number of sources.

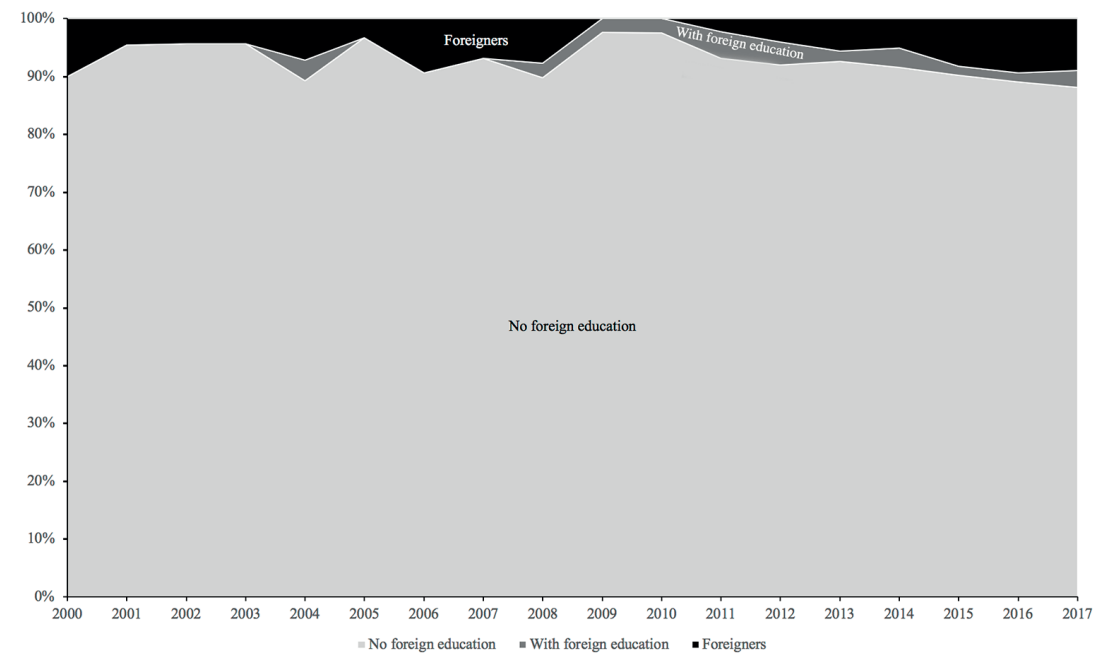

Figure 1.3 Foreign education among CEOs and board members of Russian oil companies

Source: Compiled by the authors based on a large number of sources. 
Another possible explanation for the laggardness noted above could be that Russian business is characterized by a grab-and-run mentality and, therefore, simply does not care much about long-term change. This impression is supported by the rough experiences of some foreign companies and businesspeople in Russia (Bogdanova 2015; Dahlgren 2009; Fabry and Zeghni 2002; Liuhto 2010). The post-Soviet period witnessed upheaval and socio-economic instability; property rights, in particular, were insecure and susceptible to revision (Adachi 2010; Gans-Morse 2017; Ledeneva 2013; Person 2016; Walker 2015). Fortunes were amassed and lost in short shrift, and investment horizons were correspondingly limited. The lifestyles of many Russian businesspeople seemed to indicate that they considered it more important to enjoy the moment than to secure their wealth, as they found it difficult to control or predict what would happen in the long term anyway. If this is a correct reading of post-Soviet society, Russian oil companies should, indeed, be expected to be more concerned with quick profits than with anticipating and preparing for long-term global change.

As a corollary to the assumption of post-Soviet short-termism, it could be argued that Russian oil companies are geared towards milking what remains of the Soviet resources and infrastructure rather than doing the demanding work needed to create something new and financially sustainable. Few discoveries of major oilfields have been made in the country in the past 30 years; instead, the oil companies have subsisted on the discoveries from the Soviet period and legacy fields, such as Samotlor and Vankor. Also the infrastructure was largely built during socialism, in particular the oil and gas pipelines. At times, Russia's entire post-Soviet society has seemed to be one large asset-stripping operation, selling off everything from scrap metal to human resources - and oil. In this regard, Russia is a rentier state in a very literal sense: not only does it live off the easy-come, easy-go income from oil, but within the petroleum sector it is milking the infrastructure, competencies and structures inherited from the ancien régime. According to Gustafson (2012, p. 5),

Russia's oil industry and the Russian state are not well-prepared to deal with the coming challenge. They have spent the last two decades competing for control of the inherited oil assets and rents instead of cooperating to modernize the industry better and prepare for the next stage ahead ... The result is an industry that compared with its world peers, lags behind the rapidly moving front of a global oil business that is in the midst of a technological and managerial revolution.

Another factor that may arguably weaken the capacity of Russian actors to deal with change is conservatism. The longevity of the Soviet system, and the tsarist system before it, could be interpreted as an indication of a deep conservative current in Russian society. Marxist communism originated as a fashionable ideology in the West but later metamorphosed into a range of socialist and 
social-democratic ideologies. When this fashion reached China, Cuba, Russia and Vietnam, it instead became entrenched and served as the static organizing principle for the state and society for over half a century.

It seems that many Russians like things to stay the way they are and, therefore, tend to stick their heads in the sand rather than face changing markets, technologies and social and economic systems (Kennaway 2000). It is difficult to confirm or reject such an argument unequivocally. However, through a systematic review of empirical data, we can explore the argument in question in greater detail.

\section{SUDDEN AND GRADUAL CHANGE}

We can distinguish between two main types of change faced by oil companies. The first type is sudden, taking from a few days to a few years and relating to dramatic political and economic events, such as wars, coups, international conflicts, oil price spikes and stock market crashes. Notable examples include the 2008 financial crisis, the 2014 oil price collapse, the conflict between Russia and the West over Ukraine and the ensuing sanctions targeting the Russian energy sector.

The second type of change takes place over a longer period - years or even decades. Such change may be gradual and unnoticeable, or it may be the sum of many small increments, sometimes in a pattern of two steps forward and one step back. Although it is less dramatic than a sudden change, its consequences can be as great, and the moment of realization of what is happening can be sudden. Notable examples of gradual change in the petroleum sector include the expansion of offshore oil and gas extraction in the OECD (Organisation for Economic Co-operation and Development) countries during the 1970s (Correljé 2018; Overland 2018; Wright and Boué 2018), declining production from the Soviet legacy oilfields in Western Siberia (Gustafson 2012), the shift in oil demand growth from the West to East Asia (Overland 2015), the rise of shale oil (Boersma and Johnson 2012), the increasing interconnectedness of regional gas markets due to the expansion of liquefied natural gas (LNG) (Wright 2017) and the incipient electrification of transport (Sovacool 2017).

Sudden changes are inevitably linked to gradual developments, and gradual developments may take new directions due to sudden changes. It can, therefore, be difficult to classify events such as the Paris Agreement as sudden or gradual. After years of failed negotiations in Bali, Cancun, Copenhagen, Doha and Warsaw, it was difficult to predict whether an agreement would be reached in Paris in 2015 - until it actually happened (Hufbauer and Kim 2010). On the other hand, the push towards a more comprehensive and harder-hitting climate policy has been consistent since the early 1990s (Campbell 2013; Sprinz et al. 
2016). One could, therefore, argue that it was likely that an agreement would be signed sooner or later after years of glacial negotiations.

\section{ANALYTICAL TOPICS}

In each of the company chapters that make up the bulk of this volume, we try to touch on the same topics. They can be divided into two groups. Group I topics profile each company in terms of its role in Arctic and offshore oil extraction, internationalization, transparency and innovation. Group II topics have been selected specifically to assess the companies' adaptability to a changing global environment. They include some of the major international energy developments that have affected Russian oil companies since the turn of the millennium and their responses to these developments, including the shale revolution, oil price volatility, sanctions and climate policy.

\section{Group I Analytical Topics}

\section{The Arctic}

With the decline of the onshore Soviet legacy fields, Russian companies are being forced to migrate northwards and offshore. From 2016 to 2017, Russia's Arctic oil production grew by $10 \%$ (TASS 2017). President Putin (cited in Kramer 2011) stated that the Kara Sea alone would require USD 500 billion in investments. The Arctic is financially and technologically challenging for Russian companies on their own, and international oil companies have had a standing invitation to help develop Russia's Arctic petroleum frontier (Overland et al. 2013). Consequently, the Arctic is perhaps the most important arena for interaction between Russian companies and their international peers. Despite this, the sanctions and falling oil prices largely undermined the potential for interaction from 2014 onwards (Aalto 2016).

\section{Offshore}

Russian petroleum development is increasingly taking place offshore, namely in the Arctic Ocean, the Caspian Sea and the Pacific Ocean. Not coincidentally, the sanctions against Russia over its role in the conflict in Ukraine specifically target Arctic and offshore oil and gas developments - an attempt to hit where it hurts (Fjaertoft and Overland 2015).

An important feature of offshore developments is that their costliness renders them vulnerable to oil price volatility (Overland et al. 2015). This is doubly true when they are located in the Arctic or other remote areas with harsh climatic conditions, such as the Sea of Okhotsk. The Shtokman gas and condensate field in the Barents Sea once received considerable attention from both Russian and foreign companies but was shelved because of the costs of 
developing the field as well as falling gas prices (Henderson and Moe 2016; Overland et al. 2015). When oil and gas prices drop, the competition between petroleum provinces intensifies, and the most expensive areas see a decline in investment. Russian Arctic offshore resources are especially exposed because of compounded risk. Like the rest of the Arctic, costs are driven up by the harsh climate and distance to markets; in Russia, political risk comes on top of this.

\section{Internationalization}

For Russian companies, the Arctic and offshore are frontiers where they can benefit from partnering with international companies (Aalto 2016). Some deals between the Russian and international companies are in the range of tens of billions of dollars, such as the alliance between ExxonMobil and Rosneft forged in 2011 or the agreement between Gazprom and China National Petroleum Corporation (CNPC) on gas exports signed in 2014 (Lunden et al. 2013; Sharples 2016). These relationships serve as an important interface between Russia and the world. They have sometimes been characterized by conflict and trouble, as in the relationship between BP and Gazprom over the Kovykta gas field in Siberia or between Shell and Gazprom in the areas off Sakhalin Island (Henderson and Moe 2016; Kyj and Kyj 2010; Locatelli 2006; Sevastyanov 2008). Partly because of such past quarrels and partly because of the Western sanctions against Russia, there has been a shift away from partnerships with Western companies to Chinese and other Asian oil companies (Overland and Kubayeva 2018).

The other side of this interface is the Russian oil companies' own projects overseas. For several companies, such projects have been important to diffuse risk and gain experience, access new petroleum reserves, strengthen political ties with strategic partner countries such as Venezuela or as a token of a desire to be seen as serious actors on the international scene. As a result, the Russian oil companies are present in many parts of the world (Figure 1.4).

\section{Transparency}

The more involved Russian oil companies become with Western companies and institutions, the more important it is for the Westerners that the Russian companies are seen as transparent. This is especially true when the Russian companies are listed on foreign stock exchanges with many international investors acquiring stakes. Table 1.1 gives Ivolga et al.'s (2018) assessment of the transparency of Russian companies in the petroleum sector, including small and large ones as well as subsidiaries. In this book, we provide an alternative perspective on the major companies italicized in the table. 


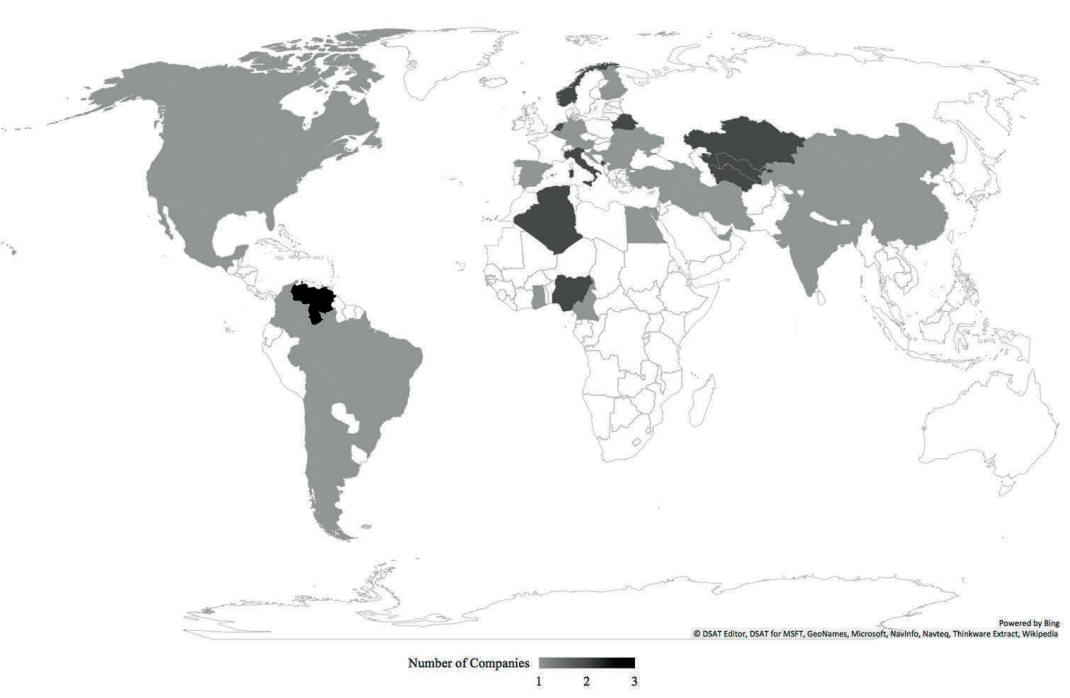

Figure 1.4 Russian petroleum foreign direct investment (FDI) projects around the world (2018)

Note: Light grey $=$ one Russian oil company present; dark grey $=$ two; black $=$ three . Source: Compiled by the authors based on a large number of sources.

Table 1.1 Transparency ratings of Russian oil and gas companies

\begin{tabular}{llll}
\hline Company & Score & Company & Score \\
\hline Zarubezhneft & 5.3 & Slavneft & 3.5 \\
Novatek & 5.1 & Transneft & 2.5 \\
RussNeft & 5.1 & Neftisa & 1.4 \\
Bashneft & 5.1 & Salym Petroleum & 1.0 \\
Rosneft & 4.9 & Transoil & 0.9 \\
Tatneft & 4.6 & Tomskneft & 0.0 \\
Gazprom & 4.4 & LUKOIL Garant & 0.0 \\
Surgutneftegas & 4.3 & Transnafta & 0.0 \\
LUKOIL & 4.1 & Eurasia Drilling & 0.0 \\
Gazprom Bureniye & 3.7 & & \\
\hline
\end{tabular}

Note: Score $0-10$, where 10 denotes most transparent. The companies covered in this book have been italicized.

Source: Ivolga et al. (2018). 


\section{Innovation}

Innovation is closely linked to foresight and thus serves as a bridge to Group II topics. In order to innovate, companies must see and understand how energy demand may develop in the future. President Putin has repeatedly called on major Russian companies to be more innovative (Putin 2017b), and Dmitry Medvedev made innovation the centrepiece of his presidency (Overland 2011). Nonetheless, there is a lingering impression that Russian oil companies are not innovative. It therefore makes sense for us to pay attention to any innovation efforts on the part of the companies.

\section{Group II Analytical Topics}

The purpose of the following set of analytical topics is to assess the adaptability of Russian oil companies to a changing global environment, in particular their responses to major international energy developments after the turn of the millennium.

\section{Shale oil and gas}

The North American shale revolution shook international markets (Figure 1.5). This development was particularly important for Russia, both as the world's largest combined oil and gas exporter and as a country that opposes the United

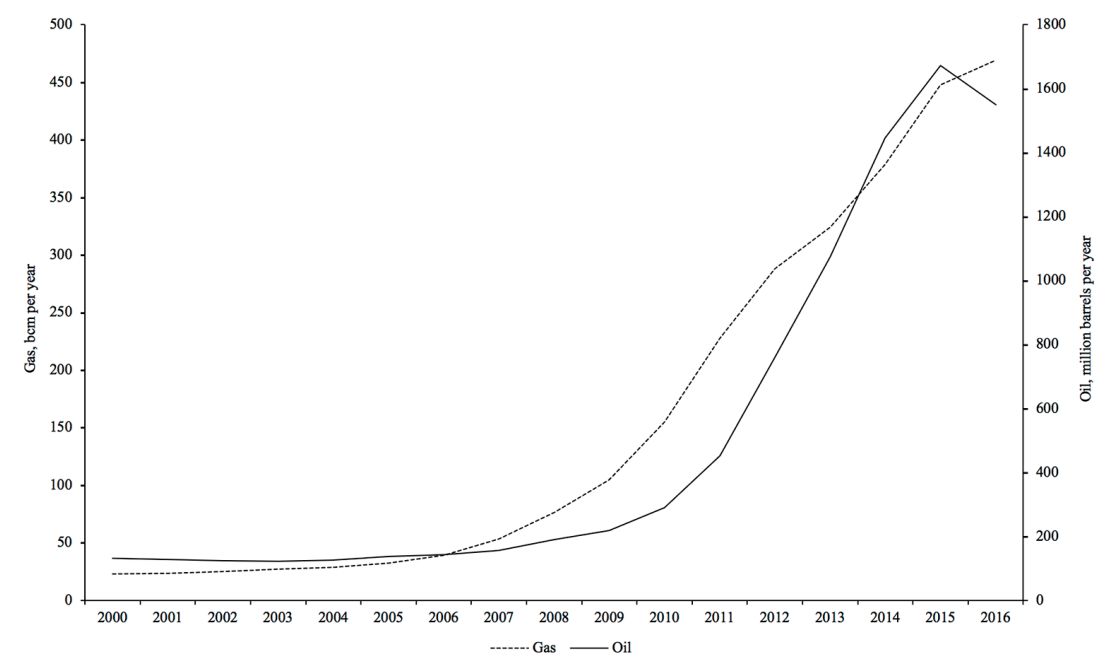

Figure 1.5 Growth in US shale oil and gas production

Source: EIA (2019a, 2019b); IEA (2019). 
States on many fronts (Overland et al. 2013, p. 146). However, for a long time, prominent Russian actors remained outspokenly sceptical about shale oil and gas (Davydova 2017b; Grealy 2012; Spencer and Hansen 2012). Deputy Head of Gazprom Alexander Medvedev referred to shale gas as 'a bubble', and chief executive officer (CEO) Alexey Miller argued that shale gas would remain a luxurious side dish: 'If you like foie gras, that doesn't mean you no longer need a regular steak' (cited in Elder 2012). Shale oil and gas are, therefore, of particular interest in a discussion of how Russian companies relate to the changing world.

\section{Oil price}

Oil companies must always be prepared for price fluctuations. From 1999 to 2008, the oil price skyrocketed from USD 20 to USD 140 per barrel; it subsequently fell to USD 40 in 2009 but bounced back again to USD 120 in 2011 and fell again to USD 30 in 2016 (Figure 1.6). As oil projects have long lead times, with decades between an investment decision and decommissioning, fluctuating prices pose a major challenge (Arezki et al. 2017; Clo 2000; Shaukat Khan et al. 2016). Gustafson (2012, p. 4) writes about the long period of rising prices from 1999 onwards: 'For the Russian elites, these were heady times - high oil prices were "here to stay" - and they became cocksure and complacent.' The same could be said of many oil-driven elites around the world.

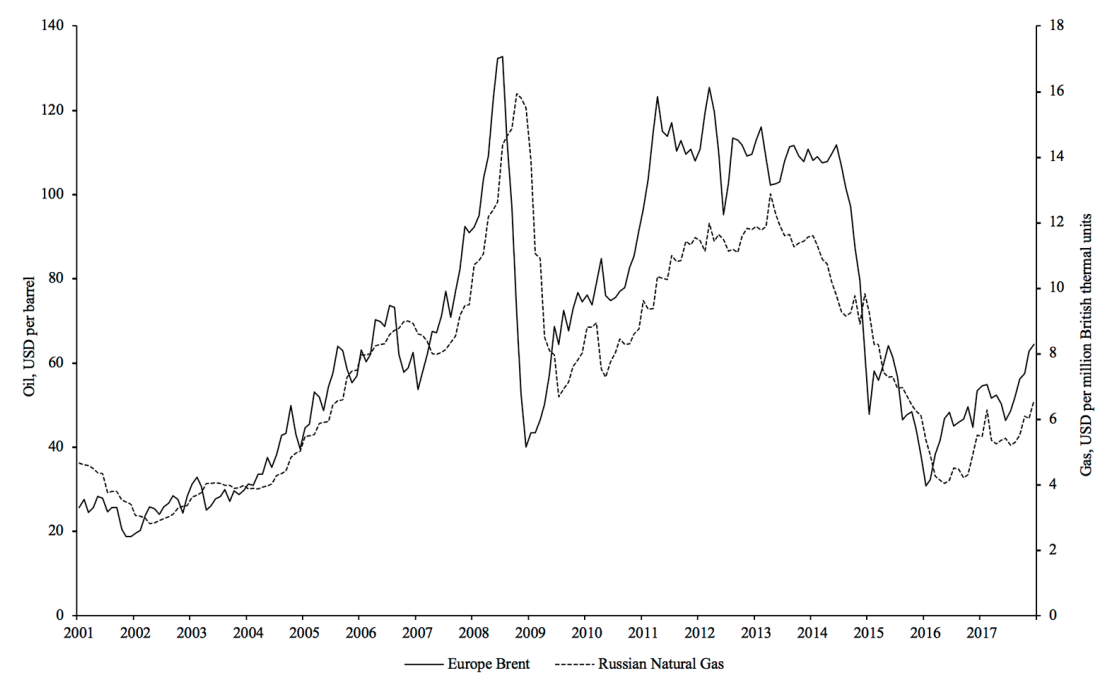

Figure 1.6 Oil and gas prices

Source: Index Mundi (2020); EIA (2020). 


\section{Sanctions}

The Western sanctions against Russia over the conflict in Ukraine targeted offshore, deep-water, unconventional and Arctic oil as well as specific Russian oil companies and individuals in the Russian petroleum sector (Fjaertoft and Overland 2015, p. 66).

The conflict in Ukraine and the introduction of sanctions against Russia coincided with the collapse of the oil price in 2014. In the preceding years, Russian oil companies had been incurring debt based on high oil price valuations of their assets and future income. The sanctions thus came at an inopportune moment for the Russian companies, revealing some of the political risks they face concerning Russian-Western relations.

\section{Climate policy and energy transition}

The most profound and long-term changes underway in the energy sector are driven by climate policy, which is increasing the pressure for a transformation of the energy mix. By 2050, there may be between $40 \%$ and $65 \%$ renewable energy in the global energy mix, up from 13\% in 2012, depending on whether one uses the scenarios of the International Energy Agency (IEA) or the International Renewable Energy Agency (IRENA) (O'Sullivan et al. 2017, p. 9). However, the scenarios of both these organizations envisage the rapid expansion of renewable energy and a corresponding lesser role for fossil fuels. While rising energy consumption may ensure that there is still a significant market for oil and gas, energy efficiency will pull in the other direction, rendering the prospects for oil companies uncertain.

Worldwide, oil companies have been slow to recognize these developments (Ben-Amar and McIlkenny 2015; Besio and Pronzini 2014; Hiatt et al. 2015; Mitchell and Mitchell 2014; Schlichting 2013). ExxonMobil's denial of climate change has received particular attention (Supran and Oreskes 2017). However, some international oil companies - such as Shell, Equinor and Total - have started positioning themselves for an energy transition by beginning to shift some capital from the petroleum sector to solar and wind power. How, then, are Russia's oil companies coping with the implications of climate change and evolving climate policy? Are they experiencing a 'Kodak moment', underestimating the potential of emerging politics and technologies and overestimating future demand for their products (Griffin et al. 2015; van der Ploeg 2016)?

On the one hand, if the companies take their cue from the official policy of the Russian state, they might not be entirely unprepared for the effects of climate policy on energy demand. Compared to China or the United States, for instance, the Russian state has been relatively consistent in its support for international climate policy in the international diplomatic arena. Unlike those two countries, Russia ratified the Kyoto Protocol, thereby enabling it to come into 
force and saving it (Henry and Sundstrom 2007, p. 47). Russia subsequently over-fulfilled its Kyoto Protocol emissions reduction targets, thus helping compensate for countries that did not fulfil their own targets (Putin 2017a). In 2013, and again in 2015, the Russian government established support schemes for renewable energy (Boute 2016). In 2017, the Working Group on Climate Change and Sustainable Development under the Presidential Administration launched an all-Russian climate week with 422 events across the country (Valeeva 2017). Of direct relevance to this book is the government's signal that it will introduce legislation limiting greenhouse gas (GHG) emissions from Russian companies and establish targets for the use of associated petroleum gas (APG) from oil production (Davydova 2017a).

However, in many other ways, Russia has remained a laggard on climate change and its oil companies might also be expected to perform below average. Russia was one of the last major greenhouse gas emitters to ratify the Paris Agreement, and Russian emissions targets do not match the country's commitments under international agreements (Sharmina 2017).

Like their American counterparts, some prominent Russians have publicly been deeply sceptical about climate change (Tynkkynen and Tynkkynen 2018; Skryzhevska et al. 2015). After visiting Franz Josef Land between the Arctic, Barents and Kara Seas, President Putin declared that climate change had nothing to do with human activity (cited in Farand 2017; Meredith and Cutmore 2017). The Executive Chairman of Rosneft, Igor Sechin, has also publicly expressed scepticism about climate change; arguing that the effect of anthropogenic greenhouse gas emissions cannot compare to those of volcano eruptions or rotting algae and stating that climate change is largely due to 30-million-year natural climatic cycles (Sechin, cited in Armitage 2015). Similar to American President Donald Trump's statement that climate change is a Chinese hoax, some major Russian media have cast climate change as a foreign plot to undermine Russian energy exports or as an American weapon aimed at Russia (Davydova 2017b). Such statements have caused some commentators to become highly critical of Russia, arguing that it is failing to adapt to the new realities of global climate policy: 'In the new geopolitics of renewable energy, post-fossil Russia does not have a value proposition ... Oil addiction is hard to cure, and Russia is not even trying' (Kraemer 2017).

As this book is about change, the forecasts of Russian governmental energy institutions are particularly relevant. Russian Minister of Energy Alexander Novak stated that electric vehicles will make up only $1 \%$ of all cars in the world by 2035 and, therefore, will not have much impact on oil demand (Novak 2016). In 2013, several top Russian energy experts published a global energy forecast that mentions renewables only once and does not mention climate change at all, although the report is 110 pages long (Makarov et al. 2013). The 2014 175-page issue of the same report mentions renewables 18 
times and climate change five times (Makarov et al. 2014). Only in the 2016 issue did the report start paying serious attention to these topics, with 24 mentions of renewable energy and 15 mentions of climate change - still not much compared to the attention these topics were attracting in the energy analyses and forecasting of many other countries (Makarov et al. 2016). In the 2019 issue, the mentions of the renewable energy and climate were still at the same level, with renewable energy mentioned 26 times and climate change 15 times (Makarov et al. 2019).

In sum, the Russian state has been sending mixed signals to the country's oil companies. How are they responding? Figure 1.7 gives a first impression of the attention of the companies to climate change. In the chapters dedicated to each company, we look more closely at how they have been handling climate policy and its implications for energy demand.

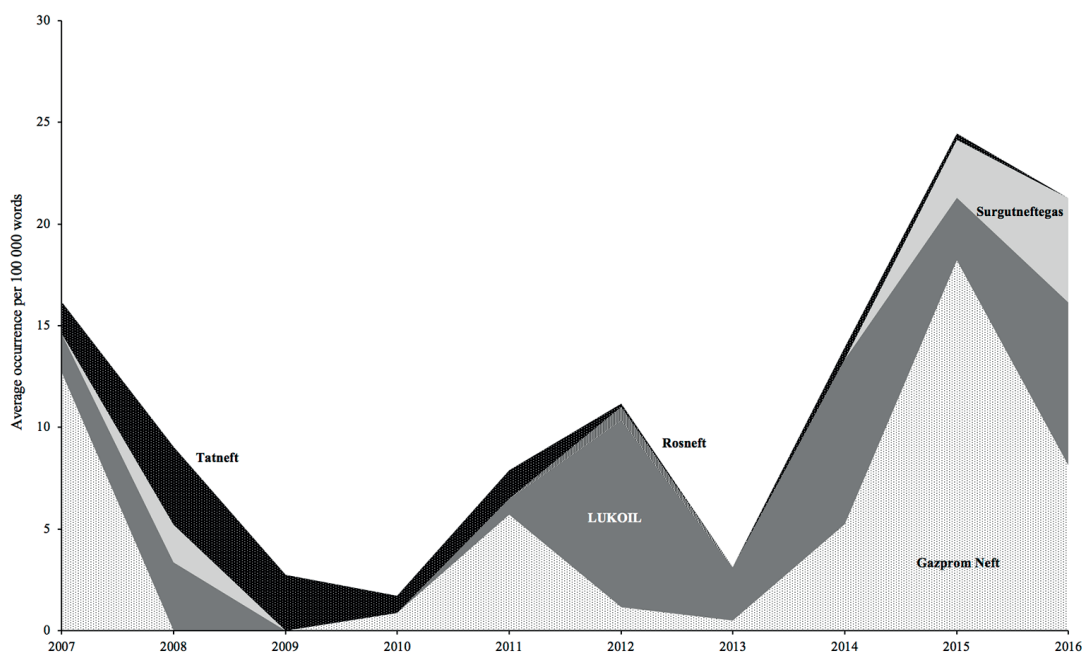

Figure $1.7 \quad$ Occurrence of 'climate change OR renewable energy' per 100000 words in Russian oil and gas company reports (2007-16)

Source: Compiled by the authors based on a large number of sources.

While we aim to cover all the topics outlined above in every chapter dedicated to a company, each company has a unique history and character, and each chapter, therefore, has a different shape. In addition to the topics outlined here, we touch on several other topics related to the Russian petroleum sector without attempting to provide detailed accounts, as these have already been provided elsewhere in the literature. This includes FDI in the petroleum sector 
(Bayulgen 2014), assessments of oil and gas fields and their decline (Grace 2005), pipeline politics (Barysch 2008; Stulberg 2012), the role of energy in foreign policy (Hill 2004), the oligarchs and elites (Balmaceda 2008; Bulavka and Buzgalin 2016; de Graaff 2012; Maury and Liljeblom 2009; Rivera and Rivera 2014), Vladimir Putin (Appel 2008; Balzer 2005; Goldman 2010), economic reform (Gaddy 2013), Dutch disease and the resource curse (Bradshaw 2006; Gaddy and Ickes 2019; Mironov and Petronevich 2015; Tompson 2005) and corruption (Cheloukhine and King 2007; Obydenkova and Libman 2015; Rutland 2015; Smith and Thomas 2015).

\section{SELECTION OF COMPANIES}

This book covers the following companies, with one chapter dedicated to each: Rosneft, LUKOIL, Gazprom Neft, Surgutneftegas and Tatneft. These five were chosen because they are the largest Russian oil companies. Their combined value is over USD 180 billion, slightly greater than the gross domestic product (GDP) of Hungary and slightly smaller than that of New Zealand (Figure 1.8). While the importance of these companies for Russia's economy, domestic politics and foreign relations is great, the academic literature on them is small.

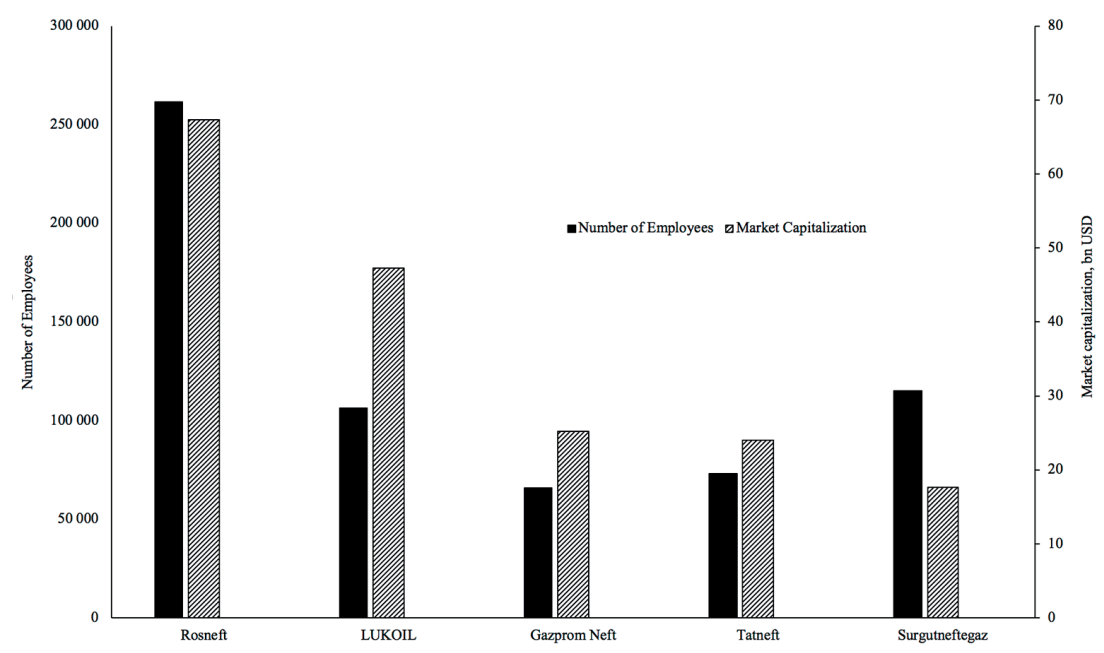

Figure $1.8 \quad$ Number of employees and market capitalization of Russian oil companies (2018)

Source: Company websites. 
Although oil-trading companies are also an important part of the Russian oil industry, we decided not to include them because some are subsidiaries of oil companies already covered in this book (for example, Litasco belongs to LUKOIL and Trumpet to Rosneft); they are mostly based outside Russia (Litasco in Switzerland, Trumpet in Ireland); employ a few people and information about them is difficult to obtain. Several companies have played important roles in the past but have been taken over by others. For example, Bashneft, Itera, Tyumen Oil Company (TNK) and YUKOS were all taken over by Rosneft, while Sibneft was taken over by Gazprom. Since this book aims to be current and forward-looking, we have chosen to focus on the current configuration of the companies rather than that of their past.

\section{CORPORATE GOVERNANCE IN RUSSIAN COMPANIES}

The governance structures of Russian companies often resemble those in the West in form but differ in content (Deloitte 2015; Kuznetsov and Kuznetsova 2009). To gain a deeper understanding of the companies discussed in this volume, it is worth highlighting some of the features of Russian corporate governance.

The general shareholder meeting constitutes the highest organ in the organizational structure of Russian companies (Tricker 2015, p. 306). Similar to companies in many Western countries, most Russian firms have a board of directors to govern the company. In practice, however, Russian boards of directors are often used as a mechanism for rubber-stamping the initiatives of influential company owners. Deals are presented to the boards for consideration at a late stage, and their job is seen as rejecting or (more likely) approving a deal but not getting involved in its details (Porshakov et al. 2010).

In a survey of company boards, Deloitte (2015) established that the average share of independent directors in Russian firms was only $43 \%$, whereas the average for the UK was $61 \%$, with $72 \%, 75 \%$ and $83 \%$ for Finland, the Netherlands and the United States, respectively. Moreover, in Russian companies, independent directors have limited access to corporate data and, therefore, little capacity to analyse the decisions they take.

In many Russian firms, in addition to the board of directors and the CEO, there is a management board in charge of the daily running of the firm. Members of the management board may make up as much as one-quarter of the board of directors, reducing the likelihood that the board will act as a check on the management (Teterevkova et al. 2017). These peculiarities of the structure of corporate governance in Russia facilitate practices such as share dilution, asset stripping, transfer pricing and ignoring the rights of minority shareholders (Adachi 2010; Porshakov et al. 2010). 
Russian companies are also highly hierarchical and the stakes for employees are high. Mid- and top-level managers are often paid well, sometimes very well. However, should they run afoul of their superiors, they can be summarily dismissed. Disobedience and failure to carry out orders are often punished harshly, for example, through de facto bans on working for any company in the industry. Unsurprisingly, Russian employees are highly disciplined and obedient: great assets under good management but less so under bad management.

\section{REFERENCES}

Aalto, P. (2016), 'Modernisation of the Russian energy sector: Constraints on utilising Arctic offshore oil resources', Europe-Asia Studies, 68 (1), 38-63.

Adachi, Y. (2010), Building Big Business in Russia: The Impact of Informal Corporate Governance Practices, London: Routledge.

Appel, H. (2008), 'Is it Putin or is it oil? Explaining Russia's fiscal recovery', Post-Soviet Affairs, 24 (4), 301-23.

Arezki, R., V.A. Ramey and L. Sheng (2017), 'News shocks in open economies: Evidence from giant oil discoveries', The Quarterly Journal of Economics, 132 (1), 103-55.

Armitage, J. (2015), 'Igor Sechin: The oil man at the heart of Putin's Kremlin', accessed 3 December 2017 at http://www.independent.co.uk/news/business/analysis-and -features/igor-sechin-the-oil-man-at-the-heart-of-putins-kremlin-10043230.html.

Balmaceda, M. (2008), Energy Dependency, Politics and Corruption in the Former Soviet Union: Russia's Power, Oligarchs' Profits and Ukraine's Missing Energy Policy, New York: Routledge.

Balzer, H. (2005), 'The Putin thesis and Russian energy policy', Post-Soviet Affairs, 21 (3), 210-25.

Barysch, K. (2008), Pipelines Politics and Power. The Future of the EU-Russia Energy Relations, London: Centre for European Reform.

Bayulgen, O. (2014), Foreign Investment and Political Regimes: The Oil Sector in Azerbaijan, Russia, and Norway, Cambridge: Cambridge University Press.

Ben-Amar, W. and P. McIlkenny (2015), 'Board effectiveness and the voluntary disclosure of climate change information', Business Strategy and the Environment, 24 (8), 704-19.

Besio, C. and A. Pronzini (2014), 'Morality, ethics, and values outside and inside organizations: An example of the discourse on climate change', Journal of Business Ethics, 119 (3), 287-300.

Boersma, T. and C. Johnson (2012), 'The shale gas revolution: U.S. and EU policy and research agendas', Review of Policy Research, 29 (4), 570-6.

Bogdanova, E. (2015), 'Cross-cultural collaboration in contemporary Russia: Problems of contracting', Journal of Social Policy Studies, 13 (1), 123-36.

Boute, A. (2016), 'Off-grid renewable energy in remote Arctic areas: An analysis of the Russian Far East', Renewable and Sustainable Energy Reviews, 59 (1), 1029-37.

Bradshaw, M. (2006), 'Observations on the geographical dimensions of Russia's resource abundance', Eurasian Geography and Economics, 47 (6), 724-46.

Bulavka, L. and A. Buzgalin (2016), 'The oligarch, the state and the intelligentsia: Khodorkovsky as a mirror of the counterpoints of post-Soviet Russia', Science \& Society, 80 (2), 248-56. 
Campbell, D. (2013), 'After Doha: What has climate change policy accomplished?', Journal of Environmental Law, 25 (1), 125-36.

Casier, T. (2011), 'The rise of energy to the top of the EU-Russia agenda: From interdependence to dependence?', Geopolitics, 16 (3), 536-52.

Cheloukhine, S. and J. King (2007), 'Corruption networks as a sphere of investment activities in modern Russia', Communist and Post-Communist Studies, 40 (1), $107-22$

Clo, A. (2000), Oil Economics and Policy, New York: Springer.

Correljé, A. (2018), 'The Netherlands: Resource management and civil society in the natural gas sector', in Indra Overland (ed.), Public Brainpower: Civil Society and Natural Resource Management, Cham: Palgrave Macmillan, pp. 181-200.

Dahlgren, L. (2009), IKEA Älskar Ryssland: En Berättelse Om Ledarskap, Passion Och Envishet, Stockholm: Natur \& Kultur.

Davydova, A. (2017a), 'Parnikovye gazy vpisyvayut v zakon', Kommersant, 35, 2.

Davydova, A. (2017b), 'Russia wants to protect itself from climate change - without reducing carbon emissions', accessed 21 November 2017 at http://www.sciencemag .org/news/2017/09/russia-wants-protect-itself-climate-change-without-reducing -carbon-emissions.

de Graaff, N. (2012), 'Oil elite networks in a transforming global oil market', International Journal of Comparative Sociology, 53 (4), 275-97.

Deloitte (2015), 'Corporate governance structures of public Russian companies', accessed 25 November 2017 at https://www2.deloitte.com/ru/en/pages/risk/articles/ 2016/corporate-governance-structures-of-public-russian-companies.html.

Dixon, S. (2008), Organisational Transformation in the Russian Oil Industry, Cheltenham, UK and Northampton, MA, USA: Edward Elgar.

EIA (2019a), 'Natural gas gross withdrawals and production', accessed 13 October 2019 at https://www.eia.gov/dnav/ng/ng_prod_sum_dc_NUS_mmcf_a.htm.

EIA (2019b), 'Petroleum \& other liquids', accessed 13 October $2 \overline{0} 19$ at https://www.eia .gov/petroleum/data.php\#crude.

EIA (2020), 'Europe Brent spot prices FOB', accessed 4 January 2020 at https://www .eia.gov/dnav/pet/hist/LeafHandler.ashx? $\mathrm{n}=$ PET\&s $=$ rbrte \& $\mathrm{f}=\mathrm{M}$.

Elder, M. (2012), 'Gazprom feels the chill as its dominance is weakened', Guardian, accessed 3 December 2017 at http://www.theguardian.com/environment/2012/nov/ 15/gazprom-chill-shale-gas-revolution.

Fabry, N. and S. Zeghni (2002), 'Foreign direct investment in Russia: How the investment climate matters', Communist and Post-Communist Studies, 35 (3), 289-303.

Farand, C. (2017), 'Vladimir Putin changes his mind and echoes Donald Trump to say humans are not to blame for climate change', accessed 29 November 2017 at http:// www.independent.co.uk/news/world/europe/vladimir-putin-russia-climate-change -not-caused-by-humans-echoes-us-trump-a7660941.html.

Fjaertoft, D. and I. Overland (2015), 'Financial sanctions impact Russian oil, equipment export ban's effects limited', Oil \& Gas Journal, 113 (8), 66-72, accessed 19 April 2020 at https://www.researchgate.net/publication/281776234_Financial Sanctions_Impact_Russian_Oil_Equipment_Export_Ban's_Effects_Limited.

Fouquet, R. (2016), 'Historical energy transitions: Speed, prices and system transformation', Energy Research \& Social Science, 22 (C), 7-12.

Fouquet, R. and P.J. Pearson (2012), 'Past and prospective energy transitions: Insights from history', Special Section: Past and Prospective Energy Transitions - Insights from History, 50 (Suppl. C), 1-7.

Friedman, T. (2006), 'The first law of petropolitics', Foreign Policy, 28-36. 
Gaddy, C. (2013), Bear Traps on Russia's Road to Modernization, New York: Routledge.

Gaddy, C. and B.W. Ickes (2019), Russia's Addiction: How Oil, Gas, and the Soviet Legacy Have Shaped a Nation's Fate, Washington, DC: Brookings Institution Press.

Gans-Morse, J. (2017), 'Demand for law and the security of property rights: The Case of post-Soviet Russia', American Political Science Review, 111 (2), 338-59.

Goldman, M. (2010), Oilopoly: Putin, Power and the Rise of the New Russia, Oxford: Oneworld Publications.

Grace, J.D. (2005), Russian Oil Supply: Performance and Prospects, Oxford: Oxford University Press.

Grealy, N. (2012), 'Gazprom as shale gas loser in denial', accessed 3 December 2017 at http://www.reimaginegas.com/?p=1991.

Griffin, P.A., A.M. Jaffe, D.H. Lont and R. Dominguez-Faus (2015), 'Science and the stock market: Investors' recognition of unburnable carbon', Energy Economics, 52, $1-12$.

Grubler, A. (2012), 'Energy transitions research: Insights and cautionary tales', Special Section: Past and Prospective Energy Transitions - Insights from History, 50 (C), $8-16$.

Gustafson, T. (2012), Wheel of Fortune: The Battle for Oil and Power in Russia, Cambridge, MA: Belknap Press.

Henderson, J. and A. Ferguson (2014), International Partnership in Russia Conclusions from the Oil and Gas Industry, Cham: Palgrave Macmillan.

Henderson, J. and A. Moe (2016), 'Gazprom's LNG offensive: A demonstration of monopoly strength or impetus for Russian gas sector reform?', Post-Communist Economies, 28 (3), 281-99.

Hendrix, C.S. (2015), 'Oil prices and interstate conflict', Conflict Management and Peace Science, 34 (6), 575-96.

Henry, L.A. and L. Sundstrom (2007), 'Russia and the Kyoto Protocol: Seeking an alignment of interests and image', Global Environmental Politics, 7 (4), 47-69.

Hiatt, S.R., J.B. Grandy and B.H. Lee (2015), 'Organizational responses to public and private politics: An analysis of climate change activists and U.S. oil and gas firms', Organization Science, 26 (6), 1769-86.

Hill, F. (2004), Energy Empire: Oil, Gas and Russia's Revival, London: Foreign Policy Centre.

Hufbauer, G.C. and J. Kim (2010), 'Reaching a global agreement on climate change: What are the obstacles?', Asian Economic Policy Review, 5 (1), 39-58.

IEA (2019), 'United States production', accessed 12 October 2019 at https://www.iea .org/ugforum/ugd/united $\% 20$ states/.

Index Mundi (2020), 'Russian natural gas monthly price - US dollars per million metric British thermal unit', accessed 3 January 2020 at https://www.indexmundi.com/ commodities/?commodity=russian-natural-gas \&months $=300$.

Ivolga, A., A. Pominov, E. Sukhareva, S. Ilya and M. Shigreva (2018), Transparency in Corporate Reporting: Assessing Russia's Largest Companies, Moscow: Transparency International.

Jirušek, M., T. Vlček and J. Henderson (2017), 'Russia's energy relations in Southeastern Europe: An analysis of motives in Bulgaria and Greece', Post-Soviet Affairs, 33 (5), 335-55.

Kalehsar, O.S. and A. Telli (2017), 'The future of Iran-Russia energy relations post-sanctions', Middle East Policy, 24 (3), 163-70. 
Kennaway, A. (2000), 'Collected writings', accessed 20 May 2018 at https://www.files .ethz.ch/isn/43988/M20_Collected.pdf.

Kotkin, S. (2008), Armageddon Averted: The Soviet Collapse, 1970-2000, Oxford and New York: Oxford University Press.

Kraemer, A. (2017), 'Can Russia imagine a post-fossil fuel future?', accessed 21 November 2017 at http://blog.iass-potsdam.de/2017/05/russia-post-fossil-fuel -future/.

Kramer, A.E. (2011), 'Exxon wins prized access to Arctic with Russia deal', New York Times, accessed 29 November 2017 at https://www.nytimes.com/2011/08/31/ business/global/exxon-and-rosneft-partner-in-russian-oil-deal.html.

Kuznetsov, A. and O. Kuznetsova (2009), 'Corporate governance in Russia: Concept and reality', in R.W. McGee (ed.), Accounting Reform in Transition and Developing Economies, Boston, MA: Springer US, pp. 445-57.

Kyj, M.J. and L.S. Kyj (2010), 'A relational framework for analyzing ventures in cognitive environments: Illustrations from the TNK-BP experience', Journal of East-West Business, 16 (4), 340-60.

Ledeneva, A. (2013), Can Russia Modernise? Sistema, Power Networks and Informal Governance, Cambridge: Cambridge University Press.

Liuhto, K. (2010), 'Political risk for foreign firms in Russia', Journal for Economic Forecasting, 3, 141-57.

Locatelli, C. (2006), 'The Russian oil industry between public and private governance: Obstacles to international oil companies' investment strategies', Energy Policy, 34, 1075-85.

Lunden, L.P., D. Fjaertoft, I. Overland and A. Prachakova (2013), 'Gazprom vs. other Russian gas producers: The evolution of the Russian gas sector', Energy Policy, 61, $663-70$.

Makarov, A.A., T.A. Mitrova and V.A. Malakhov (2013), 'Prognoz mirovoy energetiki i posledstviya dlya Rossii', accessed 20 November 2017 at https://cyberleninka.ru/ article/v/prognoz-mirovoy-energetiki-i-posledstviya-dlya-rossii.

Makarov, A.A., T.A. Mitrova, L.M. Grigoryev et al. (2014), 'Prognoz razvitiya energetiki mira i Rossii do 2040 goda', Moscow: INEI RAN, accessed 3 December 2017 at https://www.eriras.ru/files/forecast_2040.pdf.

Makarov, A.A., E.D. Belotskaya, F.V. Beselov et al. (2016), 'Prognoz razvitiya energetiki mira i Rossii 2016', accessed 20 November 2017 at http://ac.gov.ru/files/ publication/a/10585.pdf.

Makarov, A.A., V.V. Briliantova, Y.V. Galkin et al. (2019), 'Prognoz razvitiya energetiki mira i Rossii 2019', accessed 20 November 2019 at https://energy.skolkovo.ru/ downloads/documents/SEneC/Research/SKOLKOVO_EneC_Forecast_2019_Rus .pdf.

Maury, B. and E. Liljeblom (2009), 'Oligarchs, political regime changes, and firm valuation', Economics of Transition, 17 (3), 411-38.

Meadowcroft, J. (2009), 'What about the politics? Sustainable development, transition management, and long-term energy transitions', Policy Sciences, 42 (4), 323-40.

Meredith, S. and G. Cutmore (2017), 'Climate change doubters may not be so silly, says Russia's President Putin', accessed 29 November 2017 at https://www.cnbc.com/ 2017/03/30/vladimir-putin-russia-trump-us-climate-policy.html.

Mironov, V. and A. Petronevich (2015), 'Discovering the signs of Dutch disease in Russia', Resources Policy, 46, 97-112.

Mitchell, J.V. and B. Mitchell (2014), 'Structural crisis in the oil and gas industry', Energy Policy, 64 (C), 36-42. 
Novak, A. (2016), 'Intervyu Aleksandra Novaka radiostantsii "Ekho Mosvky", accessed 21 November 2017 at https://minenergo.gov.ru/node/6142.

O'Sullivan, M., I. Overland, D. Sandalow et al. (2017), 'The geopolitics of renewable energy', accessed 22 November 2017 at https://www.researchgate.net/publication/ 317954274.

Obydenkova, A. and A. Libman (2015), 'Understanding the survival of post-Communist corruption in contemporary Russia: The influence of historical legacies', Post-Soviet Affairs, 31 (4), 304-38.

Overland, I. (2011), 'Modernization after Medvedev?', Russian Analytical Digest, 105, $2-4$.

Overland, I. (2015), 'Future petroleum geopolitics: Consequences of climate policy and unconventional oil and gas', in Jinyue Yan (ed.), Handbook of Clean Energy Systems, Chichester: John Wiley, pp. 3517-44, https://doi.org/10.1002/9781118991978 .hces203.

Overland, I. (2018), 'Norway: Public debate and the management of petroleum resources and revenues', in Indra Overland (ed.), Public Brainpower: Civil Society and Natural Resource Management, Cham: Springer International Publishing, pp. 217-45.

Overland, I. and H. Kjaernet (2009), Russian Renewable Energy: The Potential for International Cooperation, Aldershot: Ashgate.

Overland, I. and G. Kubayeva (2018), 'Did China bankroll Russia's annexation of Crimea? The role of Sino-Russian energy relations', in H. Blakkisrud and E. Wilson Rowe (eds), Russia's Turn to the East: Domestic Policymaking and Regional Cooperation, Cham: Palgrave Macmillan, pp. 95-118.

Overland, I., J. Godzimirski, L.P. Lunden and D. Fjaertoft (2013), 'Rosneft's offshore partnerships: The re-opening of the Russian petroleum frontier?', Polar Record, 49 (2), 140-53.

Overland, I., A. Bambulyak, A. Bourmistrov, O.T. Gudmestad, F. Mellemvik and A. Zolotukhin (2015), 'Barents Sea oil and gas 2025: Three scenarios', in O.T. Gudmestad, I. Overland and A. Zolotukhin (eds), International Arctic Petroleum Cooperation: Barents Sea Scenarios, London: Routledge, pp. 11-32.

Peng, M. (2000), Business Strategies in Transition Economies, London: Sage.

Person, R. (2016), 'The deep impact of economic collapse on democratic support', Problems of Post-Communism, 63 (5-6), 335-53.

Porshakov, S., C. Gilbert, A. Ivakhnik and E. Chumakova (2010), 'Modern corporate governance in Russia as seen by foreign businessmen and experts', accessed 25 November 2017 at https://www2.deloitte.com/content/dam/Deloitte/ru/Documents/ finance/modern_corporate_governance_russia.pdf.

Poussenkova, N. and I. Overland (2018), 'Russia: Public debate and the petroleum sector', in Indra Overland (ed.), Public Brainpower: Civil Society and Natural Resource Management, Cham: Springer International Publishing, pp. 261-89.

Proedrou, F. (2017), 'Revisiting pipeline politics and diplomacy', Problems of Post-Communism, 65 (6), 409-18.

Putin, V. (2017a), 'Gastbeitrag von Wladimir Putin: "Wir teilen Die Deutschen prioritäten"”, accessed 21 November 2017 at http://www.handelsblatt.com/my/politik/ international/gastbeitrag-von-wladimir-putin-wir-teilen-die-deutschen-prioritaeten/ 20020620.html.

Putin, V. (2017b), 'O chem rasskazal Vladimir Putin ya plenarnom zasedanii PMEF', Rossiyskaya Gazeta, accessed 20 November 2017 at https://rg.ru/2017/06/02/reg -szfo/o-chem-rasskazal-vladimir-putin-na-plenarnom-zasedanii-pmef.html. 
Reynolds, D.B. and M. Kolodziej (2008), 'Former Soviet Union oil production and GDP decline: Granger causality and the multi-cycle Hubbert curve', Energy Economics, 30 (2), 271-89.

Rivera, D.W. and S.W. Rivera (2014), 'Is Russia a militocracy? Conceptual issues and extant findings regarding elite militarization', Post-Soviet Affairs, 30 (1), 27-50.

Rutland, P. (2015), 'Petronation? Oil, gas, and national identity in Russia', Post-Soviet Affairs, 31 (1), 66-89.

Schlichting, I. (2013), 'Strategic framing of climate change by industry actors: A meta-analysis', Environmental Communication, 7 (4), 493-511.

Sevastyanov, S. (2008), 'The more assertive and pragmatic new energy policy in Putin's Russia: Security implications for Northeast Asia', East Asia, 25 (1), 35-55.

Sharmina, M. (2017), 'Low-carbon scenarios for Russia's energy system: A participative backcasting approach', Energy Policy, 104 (C), 303-15.

Sharples, J.D. (2016), 'The shifting geopolitics of Russia's natural gas exports and their impact on EU-Russia gas relations', Geopolitics, 21 (4), 880-912.

Shaukat Khan, T., T.T.T. Nguyen, F.L. Ohnsorge and R. Schodde (2016), 'From commodity discovery to production', The World Bank, pp. 1-23.

Skryzhevska, Y., V.-P. Tynkkynen and S. Leppänen (2015), 'Russia's climate policies and local reality', Polar Geography, 38 (2), 146-70.

Smil, Vaclav (2010), Energy Transitions: History, Requirements, Prospects, Santa Barbara: ABC-CLIO.

Smith, N. and E. Thomas (2015), 'Determinants of Russia's informal economy: The impact of corruption and multinational firms', Journal of East-West Business, 21 (2), 102-28.

Sovacool, B.K. (2017), 'Experts, theories, and electric mobility transitions: Toward an integrated conceptual framework for the adoption of electric vehicles', Energy Research \& Social Science, 27, 78-95.

Spencer, B. and B. Hansen (2012), 'Russia's Gazprom skeptical of US-led shale gas boom', accessed 3 December 2017 at https://www.platts.com/latest-news/natural -gas/washington/feature-russias-gazprom-skeptical-of-us-led-shale-8545823.

Sprinz, D.F., B.B. de Mesquita, S. Kallbekken, F. Stokman, H. Sælen and R. Thomson (2016), 'Predicting Paris: Multi-method approaches to forecast the outcomes of global climate negotiations', Politics and Governance, 4 (3), 172-87.

Stulberg, A.N. (2012), 'Strategic bargaining and pipeline politics: Confronting the credible commitment problem in Eurasian energy transit', Review of International Political Economy, 19 (5), 808-36.

Supran G and N. Oreskes (2017), 'Assessing ExxonMobil's climate change communications (1977-2014)', Environmental Research Letters, 12 (8), 1-18.

TASS (2017), 'Minenergo: Zapadnye sanktsii ne povliyali na potok investitsii na shelf RF', accessed 20 November 2017 at http://tass.ru/ekonomika/4504363.

TASS (2018), 'Eksperty: Zavisimost ekonomiki RF i budzheta ot nefti snova nachala vozrastat', accessed 30 May 2018 at http://tass.ru/ekonomika/4941082.

Teterevkova, E., S. Fedorov and V. Gareev (2017), 'Corporate governance and directors' duties: Russian Federation', accessed 25 November 2017 at https:// uk.practicallaw.thomsonreuters.com/5-502-1245? transitionType=Default\& contextData $=(\mathrm{sc}$. Default $) \&$ firstPage $=$ true $\& b h c p=1$.

Tompson, W. (2005), 'The political implications of Russia's resource-based economy', Post-Soviet Affairs, 21 (4), 335-59.

Tricker, R.I. (2015), Corporate Governance: Principles, Policies, and Practices, Oxford: Oxford University Press. 
Tynkkynen, V.-P. and N. Tynkkynen (2018), 'Climate denial revisited: (Re)contextualising Russian public discourse on climate change during Putin 2.0', Europe-Asia Studies, 70 (7), 1103-20.

Valeeva, V. (2017), 'Stop the blame game: Russia is waking up to climate change', accessed 21 November 2017 at http://blog.iass-potsdam.de/2017/09/stop-blame -game-russia-waking-climate-change/.

van der Ploeg, F. (2016), 'Fossil fuel producers under threat', Oxford Review of Economic Policy, 32 (2), 206-22.

Walker, C. (2015), 'Stability and precarity in the lives and narratives of working-class men in Putin's Russia', Social Alternatives, 28 (34), 28-34.

Wigell, M. and A. Vihma (2016), 'Geopolitics versus geoeconomics: The case of Russia's geostrategy and its effects on the EU', International Affairs, 92 (3), 605-27.

Wright, P. and J.C. Boué (2018), 'The United Kingdom: Public debate and the management of petroleum resources', in Indra Overland (ed.), Public Brainpower: Civil Society and Natural Resource Management, Cham: Palgrave Macmillan, pp. 329-46.

Wright, S. (2017), 'Qatar's LNG: Impact of the changing East-Asian market', Middle East Policy, 24 (1), 154-65. 